AGRICULTURE AND BIOLOGY JOURNAL OF NORTH AMERICA

ISSN Print: 2151-7517, ISSN Online: 2151-7525, doi:10.5251/abjna.2011.2.3.454.461

(C) 2011, ScienceHu $\beta$, http://www.scihub.org/ABJNA

\title{
The potentials of mineral oils for controlling the major insect pests of cowpea (Vigna unguiculata (L.) Walp in Asaba, Nigeria
}

\author{
E.O. Egho \\ Deptartment of Agronomy, Faculty of Agriculture, Delta State University, Abraka
}

\begin{abstract}
Three mineral oils - premium motor spirit (PMS), dual purpose kerosene (DPK) and automotive gas oil (AGO) at $0.4 \%$ concentration each, were evaluated for efficacy in the control of major insect pests and yield of cowpea. Insect pests studied were the cowpea aphid, Aphis craccivora Koch, legume bud thrips Megalurothrips sjostedti Tryb, legume pod borer, Maruca vitrata Fab. and pod sucking bugs. The trials were carried out in the teaching and research farms at the Agronomy department, Asaba Campus, Delta State University, Nigeria. The results showed that the tested mineral oils effectively controlled $M$. sjostedti damage and PMS and AGO controlled $M$. vitrata during the early season. In the late season study, DPK was effective against $A$. craccivora. All the tested mineral oils controlled pod sucking bugs. Moderate yields of $224.70 \mathrm{~kg}$ $\mathrm{ha}^{-1}, 238.20 \mathrm{~kg} \mathrm{ha}^{-1}$ and $397.00 \mathrm{~kg} \mathrm{ha}^{-1}$ for PMS, DPK and AGO respectively were obtained in the early season. Yields in the late season were lower compared to early season yield. There was delay and reduced flowering of cowpea in the field with mineral oil application. The study provides the information that mineral oils can be reliable insecticides for cowpea growers if these factors - delay and reduction of flowering are removed, they could be new components in the overall management of cowpea pests in Nigeria.
\end{abstract}

Keywords: Cowpea, insect pests, mineral oils, Asaba, Southern Nigeria.

\section{INTRODUCTION}

Among the constraints in crop production in tropical and subtropical regions of the world are the activities of insect pests on economic crops in the field and storage. One major food crop that has been so much plagued and damaged by insect pests is the legume, cowpea (Vigna unguiculata (L.) Walp). It is now known that a spectrum of insect pests decimate the crop at all stages of growth (Jackai, 1988). These insects which include the cowpea aphid, Aphis craccivora, Koch, flower bud thrips, Megalurothrips sjostedti Trymb, the legume pod borer, Maruca vitrata Fab, and a complex of pod sucking bugs among which are Clavigralla tomentosicollis, Anoplocnemis curvipes Fab, Aspavia armigera Fab and Nezera viridula $L$ have been reported to cause low yield in cowpea in Africa (Olatunde et al., 1991). Man has, therefore, been deprived of the maximum benefit from cowpea cultivation as cheap source of protein (IITA, 1984; Alabi et al., 2003), fibre (Rachie, 1985) and fodder for livestock (Job et al., 1983). Faced with challenges from insect pests, various control measures such as use of synthetic chemicals and host plant resistance (HPR) (Jackai, 1983, 1985) are being used to curtail insect activities. The use of chemicals as commonest and widely practiced (Jackai and Daoust, 1986; Jackai, 1993; Kurangi et al., 2000) have been reported in African countries. However, because of serious deleterious side effects such as toxicity to mammals, users, consumers, non target organisms, environmental pollution (Alabi et al., 2003) and high cost of insecticides and equipment (Afun et al., 1991) there is outcry worldwide against unilateral chemical usage as method of pest management.

Stern (1973) however cautioned against total abandonment of chemicals since it would worsen food crisis in Africa. In the search for suitable chemicals, non-conventional chemicals such as plant derivatives and mineral oils (bio-chemicals) with insecticidal property have recently attracted the attention of researchers and several of them that are inexpensive and ecologically acceptable have been reported (Arnason et al., 1989; Jackai, 1993).

Mineral oils, refined products of petroleum, have been reported effective against insect pests of several crops (e.g. cotton) in many parts of the world (Nagar et al., 2007a, 2007b; Aldabel et al., 2007; Mensah et al., 2005a, 2005b). There is presently 
dearth of information for field pest control on arable crops with mineral oils in Nigeria.

This study therefore evaluated the insecticidal property of three mineral oils (chemicals) premium motor spirit (PMS), dual purpose kerosene (DPK) and automative gas oil (AGO) (as non-conventional chemicals) for the control of cowpea insect pests during the early and late planting seasons at Asaba, Delta State, Southern Nigeria.

\section{MATERIALS AND METHODS}

The trials were carried out during the early and late planting seasons of 2005, in the Teaching and Research farms of the Agronomy Department, Delta State University, Asaba Campus, Oshimili South LGA, Delta State. The land was ploughed and harrowed with a tractor in the early season while it was manually prepared with shovels and hoes in the late season. The experimental plot size for the study was $5 \mathrm{~m} \times 3 \mathrm{~m}$ with $1.5 \mathrm{~m}$ in-between plots. The cowpea seeds planted were Ife brown (obtained from the International Institute of Tropical Agriculture (IITA) Ibadan. For the early season, the seeds were planted on 29th May and 17th September for the late season, 2005. Three seeds were planted per hole with planting spacing of $60 \mathrm{~cm} \times 30 \mathrm{~cm}$ (Remison, 1978e). Seeds that failed to sprout after four days were replaced. Each plot consisted of 6 rows of 36 cowpea stands. The farm was regularly weeded until plant maturity.

The experiment was organised into a randomized complete block design with 5 treatments and 3 replicates. The treatments were plots sprayed with premium motor spirit (PMS), dual purpose kerosene (DPK), automotive gas oil (AGO) cypermethrin (CPM) and plots without insecticide treatments (control). The concentration used in each mineral oil was $0.4 \%$. Four major insect pests of cowpea were targeted for management.

Aphis craccivora: This was determined by visual rating based on a 10 point scale (Litsinger et al., 1977). A. craccivora colony was observed weekly on 20 randomly selected cowpea stands in the 2 middle rows of each plot. Each colony was visually scored and mean calculated. Six observations were made beginning from 26 DAP between 8.00 a.m. and 10.00 a.m.

Megalurothrips sjostedti (flower thrips): The damage to cowpea flower buds by $M$. sjostedti was visually rated on a scale of 1-9 points, based on known symptoms of $M$. sjostedti damage to cowpea such as browning/drying of stipules, leaf or flower buds (Jackai and Singh, 1988). From 20 randomly tagged cowpea plants, in the 2 middle rows of each plot, the plants were inspected for symptoms and scored and the mean score calculated. Observations for symptoms commenced at 30 DAP (when peduncles were $2-3 \mathrm{~cm}$ long) at the intervals of 6 days between 8.00 a.m. and 10.00 a.m. Four observations were made.

Maruca vitrata: The damage to cowpea by $M$. vitrata was assessed by observing (examining) 20 cowpea flowers, randomly selected from the 2 outer cowpea rows of each plot. Each flower was carefully opened and examined on the spot between $3.00-5.00$ p.m. and presence of Maruca larva/damage to flower recorded. Flower examination commenced at 45 DAP at five days intervals and ended at 60 DAP. Four observations were made. Population of $M$. sjostedti (number per flower) and an insect which fed on cowpea flower pollen, was also visually counted and recorded when each flower was opened and examined for Maruca damage.

Pod sucking bugs: Damage to cowpea by pod sucking bugs was assessed from the 2 middle rows of each plot by counting between 8.00 a.m. and 10.00 a.m. All bugs beyond the nympal phase were counted and since damage to cowpea by bugs are similar, all bugs were counted together. Observations commenced at 45 DAP at 5 days' interval and ended at 55 DAP. Three observations were made. Counts were recorded and mean score calculated.

\section{YIELD AND YIELD RELATED COMPONENTS}

Yield Data: At 65 DAP, the pods were harvested according to treatments with hands into black polyethylene bags. They were sundried for 2 weeks and shelled with hands. The grains were then weighed with triple beam balance (Haus model) and weights recorded. The yield per plot was extrapolated to $\mathrm{kg} \mathrm{ha-}{ }^{1}$. One hundred seeds were hand-picked from the grains in each bag (plot); they were weighed and the weight recorded.

\section{Yield related components:}

(i) Pod load and pod damage: Pod load and pod damage were determined in the field at 60 DAP by visual rating on a scale of 1-9 (Jackai and Singh, 1988) from the 2 central rows of each plot. Holes and presence of frass on pods and sticking of pods were used as pod damage index by Maruca.

(ii) Pod evaluation index (Ipe) was determined with the formula below:PL $\times(9-P D)$ where PL was 
pod load and PD was pod damage. (Jackai and Singh, 1988)

(iii) Number of pods per plant: This was assessed from the 2 middle rows of each plot at 60 DAP. One metre length of cowpea row in the 2 middle rows was taken with 1 metre long ruler. The length was marked with 2 sticks. The pods and plants that fell within this distance were counted. The number of pods were then divided by the number of cowpea plants and the value recorded.

No. of pods $=$ No. of pods per plant

No. of plants

(iv) Pod and seed damage: Damage to pods and seeds by pod sucking bugs was assessed by examining the pods and seeds in the laboratory. Cowpea pods in the two middle rows in each plot were harvested at maturity into medium size black polyethylene bags according to plot number and were sundried for one week. From each bag, 20 pods were hand-picked randomly. Each was measured with a flexible thread to determine its length. Each pod was then opened with hand. The number of seeds per pod, aborted seeds per pod, wrinkled seeds per pod and seeds with feeding lesions per pod were observed, recorded and the mean calculated.

Data for insect observation, yield and yield related components were subjected to analysis of variance (ANOVA) and significant means were separated by Fisher's Least Significant Difference Test (LSD), at $5 \%$ level of significance.

\section{RESULTS}

The effects of mineral oils and cypermethrin application for the control of major insect pests on cowpea during the early and late season experiment at Asaba are given in Table 1 . In the early season experiment, all the major insect pests targeted for management except, $A$. craccivora were observed in the study area. Insecticide protected plots significantly $(P<0.05)$ reduced $M$. sjostedti damage to cowpea when compared to control plots. The CPM was significantly more effective in reducing $M$. sjostedti damage than other treatments except AGO treated plots. AGO was slightly more effective in reducing $M$. sjostedti damage than PMS and DPK, though not significantly different from them. For flower bud thrips, the CPM significantly $(P<0.05)$ reduced the population when compared with other treatments. The PMS, DPK and AGO treatments were not significantly different in reducing thrip population when compared to the control. In the case of $M$. vitrata, similar trend was observed, with CPM significantly $(P<0.05)$ reducing $M$. vitrata damage when compared with other treatments. Pod sucking bugs (PSB) populations were generally low in all treatments. Treatments were not significantly different in reducing the PSB population when compared with the control.

All the major insect pests were recorded on the crop, in the study area during the late season (Table 1). DPK and CPM treatments significantly $(P<0.05)$ reduced aphid population when compared to the control. The PMS and AGO did not significantly (P > $0.05)$ reduce the population compared to the control. DPK was significantly $(P<0.05)$ more effective in reducing the population when compared with PMS and AGO. For the $M$. sjostedti damage to cowpea, all the treatments significantly $(P<0.05)$ reduced damage on cowpea when compared to control. However, differences among the treatments in their effects on $M$. sjostedti damage were not significant.

All mineral oils treatments against the thrip population did not significantly $(P>0.05)$ reduce population when compared with the control. However, the CPM treatment significantly reduced the thrip population compared with other treatments. For $M$. vitrata, the treatments did not significantly $(P>0.05)$ reduce Maruca damage to flowers when compared to the control. In the case of PSB, all the treatments did not significantly $(P>0.05)$ reduce the bug population when compared with the control although the control was slightly higher than the other treatments.

The seasonal effect on insect pest population under mineral oil and CPM application at Asaba is presented in table 2 .

Late season population of $A$. craccivora, flower bud thrips and pod sucking bugs were significantly $(\mathrm{P}<0.05)$ higher in the late season compared with early season. Conversely, early season damage to cowpea by $M$. sjostedti was significantly higher in the early season than late season. There was no significant difference in damage to cowpea flower by M. vitrata when early and late seasons were compared.

Season at Asaba.

Effect of mineral oils on cowpea yield and yield related component during the early and late season experiments at Asaba is presented in Table 3. 
Agric. Biol. J. N. Am., 2011, 2(3): 454-461

Table 1: Effect of mineral oils application on the major insect pests of cowpea in the early and late seasons at Asaba, Nigeria.

\begin{tabular}{|c|c|c|c|c|c|c|}
\hline & Treatments & $\begin{array}{l}\text { Aphis craccivora } \\
\text { (rating) }\end{array}$ & $\begin{array}{l}\text { Megalurothrips } \\
\text { sjostedti } \\
\text { (rating) }\end{array}$ & $\begin{array}{l}\text { Flower bud } \\
\text { thrips }{ }^{\star} \\
\text { (actual counting) }\end{array}$ & $\begin{array}{l}\text { Maruca vitrata* } \\
\text { (actual } \\
\text { counting) }\end{array}$ & $\begin{array}{l}\mathrm{PSB}^{\star \star} \\
\text { (actual counting) }\end{array}$ \\
\hline \multirow{6}{*}{ 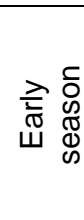 } & CONTROL & & 2.18 & 2.80 & 0.28 & 0.11 \\
\hline & PMS & & 2.03 & 3.21 & 0.24 & 0.00 \\
\hline & DPK & & 1.96 & 2.77 & 0.29 & 0.00 \\
\hline & AGO & & 1.56 & 2.85 & 0.25 & 0.00 \\
\hline & CPM & & 1.21 & 1.15 & 0.13 & 0.00 \\
\hline & $\operatorname{LSD}(0.05)$ & & 0.56 & 0.96 & 0.09 & NS \\
\hline \multirow{6}{*}{ 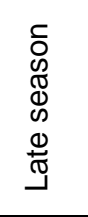 } & CONTROL & 0.78 & 1.98 & 7.99 & 0.13 & 6.56 \\
\hline & PMS & 1.06 & 1.33 & 7.50 & 1.36 & 4.45 \\
\hline & DPK & 0.00 & 1.33 & 7.12 & 0.14 & 5.67 \\
\hline & AGO & 0.78 & 1.50 & 7.13 & 0.11 & 5.00 \\
\hline & CPM & 0.00 & 1.50 & 3.65 & 0.10 & 5.22 \\
\hline & $\operatorname{LSD}(0.05)$ & 0.70 & 0.40 & 1.77 & NS & NS \\
\hline
\end{tabular}

PMS - Premium motor spirit, DPK- Dual purpose kerosene, AGO - Automotive gas oil,

CPM - Cypermethrin, N.S - Not significant

* Means of 20 flowers

** Number per 2-middle rows

Table 2: The seasonal effect of the application of mineral oils on the major insect pests of cowpea at Asaba, Nigeria.

\begin{tabular}{|l|c|c|c|c|c|}
\hline \multicolumn{1}{|c|}{ Treatments } & $\begin{array}{c}\text { Aphis craccivora } \\
\text { (rating) }\end{array}$ & $\begin{array}{c}\text { Megalurothrips } \\
\text { sjostedti (rating) }\end{array}$ & $\begin{array}{c}\text { Flower bud thrips } \\
\text { (actual counting) }\end{array}$ & $\begin{array}{c}\text { Maruca vitrata* } \\
\text { (actual } \\
\text { counting) }\end{array}$ & $\begin{array}{c}\text { PSB }^{\star \star} \\
\text { (actual counting) }\end{array}$ \\
\hline Early & 0.00 & 1.79 & 2.56 & 0.24 & 0.02 \\
Late & 0.52 & 1.53 & 6.68 & 0.37 & 7.40 \\
LSD (0.05) & 0.22 & 0.21 & 0.63 & NS & 1.52 \\
\hline
\end{tabular}

* Means of 20 flowers

** Number per 2 middle rows

NS-Not significant

Yields in early season, did not significantly differ in the various treatments and when compared to control. The unprotected plots (control) however, slightly had lower yields than AGO and CPM protected plots. Among the treatments, yields were slightly more in cypermethrin protected plots than the mineral oil protected plots. Plots protected with PMS had the least yield. Yield related components such as pod length, pod load, pod damage and seeds with feeding lesions did not show significant difference among the treatments and when compared to control. However, 100 seed weight, number of pods/plant, number of seeds per/pod, pod evaluation index, aborted seeds/pod and wrinkled seeds/pod showed significant difference among the treatments.

In the late season (Table 3 ), mineral oil treated plots did not significantly $(P>0.05)$ increase yields when compared with plots without insecticide treatment. The CPM however, significantly increased $(P<0.05)$ yield compared to control and the other treatments. In the late season, all yield related components, except wrinkled seeds /pod and seeds with feeding lesions showed significant difference among the treatments.

The seasonal effect on cowpea yield and yield related components under the application of mineral oils and conventional insecticide during the early and late seasons at Asaba is presented in Table 4.

For grain yields, early cowpea yields were higher and significantly $(P<0.05)$ higher than late cowpea yields. Late season had significantly $(P<0.05)$ higher number of pods per plant than early cowpea pods. Pod length was significantly longer in the early season than late season while yield components like number of pods/plant, pod damage and wrinkled seeds/pods were significantly more in the late season, compared with early. There was no significant difference between early and late seasons for 100 seed weight, pod load, pod evaluation index, aborted seeds/pod and seeds with feeding lesions. 
Agric. Biol. J. N. Am., 2011, 2(3): 454-461

Table 3: Effect of mineral oils and cypermethrin on yield and yield related components from cowpea in the early and late season at Asaba, Nigeria

\begin{tabular}{|c|c|c|c|c|c|c|c|c|c|c|c|c|}
\hline & Treatments & $\begin{array}{l}\text { Dry Grain } \\
\text { yield (kg } \\
\mathrm{ha}^{-1} \text { ) }\end{array}$ & $\begin{array}{l}100 \text { seeds } \\
\text { wt(g) }\end{array}$ & $\begin{array}{l}\text { Number of } \\
\text { pods/ } \\
\text { plant } \\
\text { (approx) }\end{array}$ & $\begin{array}{l}\text { Pod length } \\
\text { (cm) }\end{array}$ & $\begin{array}{l}\text { Number of } \\
\text { seeds/pod }\end{array}$ & Pod load & $\begin{array}{l}\text { Pod } \\
\text { damage }\end{array}$ & $\begin{array}{l}\text { Pod } \\
\text { evaluation } \\
\text { index }\end{array}$ & $\begin{array}{l}\text { Aborted } \\
\text { seeds/pod }\end{array}$ & $\begin{array}{l}\text { Wrinkled } \\
\text { seeds/pod }\end{array}$ & $\begin{array}{l}\text { Seeds with } \\
\text { feeding } \\
\text { lesions }\end{array}$ \\
\hline 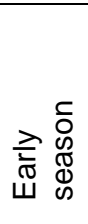 & $\begin{array}{l}\text { CONTROL } \\
\text { PMS } \\
\text { DPK } \\
\text { AGO } \\
\text { CPM } \\
\text { LSD }(0.05)\end{array}$ & $\begin{array}{l}269.10 \\
224.70 \\
238.20 \\
397.00 \\
498.20 \\
\text { NS }\end{array}$ & \begin{tabular}{l|}
12.43 \\
13.10 \\
12.50 \\
13.80 \\
12.80 \\
1.35
\end{tabular} & $\begin{array}{l}3.59 \\
2.75 \\
2.15 \\
4.11 \\
6.83 \\
4.05\end{array}$ & $\begin{array}{l}14.14 \\
14.00 \\
13.78 \\
14.61 \\
15.05 \\
\text { NS }\end{array}$ & \begin{tabular}{l|}
12.37 \\
12.25 \\
11.90 \\
13.15 \\
14.04 \\
1.53
\end{tabular} & $\begin{array}{l}4.33 \\
6.33 \\
5.00 \\
5.67 \\
7.67 \\
\text { NS }\end{array}$ & $\begin{array}{l}5.33 \\
3.67 \\
5.00 \\
4.00 \\
2.00 \\
\text { NS }\end{array}$ & \begin{tabular}{l|}
22.33 \\
34.67 \\
28.00 \\
29.00 \\
54.33 \\
29.99
\end{tabular} & $\begin{array}{l}1.53 \\
2.23 \\
1.85 \\
2.22 \\
3.68 \\
1.40\end{array}$ & $\begin{array}{l}2.13 \\
1.80 \\
1.83 \\
1.28 \\
0.47 \\
0.78\end{array}$ & $\begin{array}{l}0.35 \\
0.17 \\
0.20 \\
0.33 \\
0.12 \\
\text { NS }\end{array}$ \\
\hline 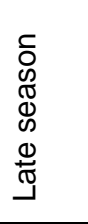 & $\begin{array}{l}\text { CONTROL } \\
\text { PMS } \\
\text { DPK } \\
\text { AGO } \\
\text { CPM } \\
\text { LSD }(0.05)\end{array}$ & $\begin{array}{l}158.88 \\
63.44 \\
132.99 \\
73.00 \\
480.55 \\
266.37 \\
\end{array}$ & $\begin{array}{l}14.70 \\
11.13 \\
13.38 \\
8.27 \\
15.60 \\
5.91\end{array}$ & $\begin{array}{l}3.17 \\
4.44 \\
5.38 \\
4.28 \\
8.80 \\
2.06 \\
\end{array}$ & $\begin{array}{l}11.55 \\
11.44 \\
11.53 \\
10.85 \\
13.06 \\
1.35\end{array}$ & $\begin{array}{l}7.98 \\
6.71 \\
7.65 \\
6.10 \\
11.12 \\
2.56 \\
\end{array}$ & $\begin{array}{l}4.33 \\
5.67 \\
5.00 \\
5.00 \\
9.00 \\
2.57\end{array}$ & $\begin{array}{l}7.00 \\
5.33 \\
5.00 \\
6.33 \\
2.00 \\
1.52 \\
\end{array}$ & $\begin{array}{l}11.33 \\
20.33 \\
20.00 \\
14.67 \\
63.00 \\
13.73 \\
\end{array}$ & $\begin{array}{l}1.62 \\
2.10 \\
1.73 \\
2.98 \\
0.30 \\
1.91\end{array}$ & $\begin{array}{l}3.10 \\
3.80 \\
3.42 \\
1.98 \\
2.20 \\
\text { NS }\end{array}$ & $\begin{array}{l}0.28 \\
0.13 \\
0.22 \\
0.15 \\
0.03 \\
\text { NS }\end{array}$ \\
\hline
\end{tabular}

PMS - Premium motor spirit, DPK- Dual purpose kerosene, AGO - Automotive gas oil,

CPM - Cypermethrin, N.S - Not significant

Table 4: Seasonal effect on yield and yield related components from cowpea under the application of mineral oil at Asaba, Nigeria

\begin{tabular}{|c|c|c|c|c|c|c|c|c|c|c|c|}
\hline Season & $\begin{array}{l}\text { Dry Grain } \\
\text { yield (kg } \\
\left.\mathrm{ha}^{-1}\right)\end{array}$ & $\begin{array}{l}100 \text { seeds } \\
\text { wt }(\mathrm{g})\end{array}$ & $\begin{array}{l}\text { Number of } \\
\text { pods/ } \\
\text { plant } \\
\text { (approx) }\end{array}$ & $\begin{array}{l}\text { Pod length } \\
(\mathrm{cm})\end{array}$ & $\begin{array}{l}\text { Number of } \\
\text { seeds/pod }\end{array}$ & Pod load & $\begin{array}{l}\text { Pod } \\
\text { damage }\end{array}$ & $\begin{array}{l}\text { Pod } \\
\text { evaluation } \\
\text { index }\end{array}$ & $\begin{array}{l}\text { Aborted } \\
\text { seeds/pod }\end{array}$ & $\begin{array}{l}\text { Wrinkled } \\
\text { seeds/pod }\end{array}$ & $\begin{array}{l}\text { Seeds with feeding } \\
\text { lesions }\end{array}$ \\
\hline Early & 325.44 & 12.93 & 3.89 & 14.11 & 12.74 & 5.80 & 4.00 & 33.67 & 2.30 & 1.50 & 0.23 \\
\hline Late & 181.77 & 12.62 & 5.21 & 11.69 & 7.91 & 5.80 & 5.13 & 25.87 & 1.75 & 2.90 & 0.16 \\
\hline $\operatorname{LSD}(0.05)$ & 105.38 & NS & 1.28 & 0.58 & 0.86 & NS & 1.12 & NS & NS & 0.74 & NS \\
\hline
\end{tabular}

PMS - Premium motor spirit, DPK- Dual purpose kerosene, AGO - Automotive gas oil,

CPM - Cypermethrin, N.S - Not significant 


\section{DISCUSSION}

The results on the control of $M$. sjostedti on cowpea damage clearly revealed the reliability of mineral oils in the control of the pest in the field at Asaba, Nigeria during the early planting season. In Australia, mineral oils have been used to control Aphis gossypii, Glover, on cotton (Najar et al., 2007a and b). Similar work using petroleum spray oils to suppress the activities of insect pests on crops have also been reported (Aldabel et al., 2007; Mensah et al., 2005a, 2005b; 2002, Najar et al., 2006). In Israel, mineral oils have been successfully used as contact insecticide to control insect pests on various crops (Emosairue, 2009 - personal communication). From this study, AGO was most effective on $M$. sjostedti among the mineral oils. This probably was due to its highly repulsive property when compared to the other mineral oils. Although, literature on mineral oils as tools for the control of field pests is lacking in Nigeria, this work supports the use of petroleum spray oils as effective chemicals as reported by earlier researchers (Najar et al., 2007; Al-dabel et al., 2007; Mensah et al., 2005a, 2005b; 2002 ). This study shows that barring economic consideration mineral oils could be a new component in the overall management of cowpea pests in Nigeria. On thrip population, mineral oils was not effective in checking the population. This may again be due to sudden population pressure of the insect after the chemicals have been washed away and lost its potency. The result also revealed that $M$. vitrata damage and PSB population were not affected by mineral oils application as repellant. The CPM on the other hand, was effective in suppressing $M$. sjostedti and M. vitrata as have been reported by Jackai (1985). The low population of PSB at this season as noted in this study is in agreement with Dina (1982) who reported that PSB's population was generally low during the off season (early planting)

During the late season, the results showed that of the mineral oils, DPK was more effective in controlling $A$. craccivora, when compared with PMS and AGO. DPK is usually more pungent and repelling than PMS and AGO. This property of DPK could have made it to have more residual effect on the crops and thus caused it to exert its protective effect. On PMS and AGO, they are highly volatile liquid and their insecticidal activities may have been lost shortly after application and could not deter the establishment of the insect. The CPM effectively controlled $A$. craccivora. This study agrees with previous reports such as Jackai et al. (1988) who used carbosulfan (a synthetic pyrethriod) to control aphids.
The results have revealed that $M$. sjostedti damage to cowpea was reduced by mineral oils. This seems to suggest that $M$. sjostedti is highly sensitive to mineral oils at 0.4 concentration and as contact insecticide, mineral oils could have killed the insect and prevented it from damaging the flower buds. On thrips, the mineral oils did not control the population. This result seems to contradict the above reports on thrip damage. One would expect that since the mineral oils prevented thrip damage, the thrip population (or insect number) would reduce. Possibly thrip population increased at a stage when insecticide application had stopped and flower buds formation had ceased at about 45DAP. Like the thrip population, mineral oils did not have effect on $M$. vitrata. The insect could have been protected from chemicals because it was in its burrows - in flowers and fruits. Jackai (1983b) reported that Maruca larvae could probably escape effects of chemicals due to the ability of the insect to detoxify chemicals although no literature on this, he added. It could be that mineral oils as contact insecticide (in mode of action) could not get to the hideouts of Maruca larvae and thus rendering the chemical ineffective. PSB population was not affected by mineral oils application. At podding stage of cowpea, usually at 45DAP, PSB population is increased especially in plots with high successful podding. Furthermore, the angles created by the numerous pods in cowpea have been suggested as possible hideouts for cowpea pests to escape from parasites and predators (Karungi et al., 2000) and possibly too, effect of chemicals. In control plots, PSB population was low because pod formation was poor. This result revealed that more PSB number would be encountered in mineral oils plots than controlled plots.

A. craccivora being more in the late season is expected as this has been the general trend when cowpea is cultivated at this time. Sunshine and less rain have probably been factors which enhanced the activities of this insect. In this study, M. sjostedti damage was higher in the early season- an observation contrary to Ngakou (2006) who reported reduced adult thrip populations under caging and deltamethrin spray conditions. Probably, this may due to the non harmful effect of the chemical on the insect. The insect usually hides and feeds on flower buds. The chemical may not have got to them in the flower bud. Further more, a washing away of the chemical could have occurred. The higher population of flower bud thrips in the late season as indicated in this study may be due to the season and reasons 
given earlier on flower thrips at this period of cowpea production. Karungi et al. (2000) reported Maruca infestations on cowpea at both seasons to be non significant. This study however, noted that Maruca damage was more in the late season; probably, an upsurge of Maruca population could have occurred after mating during the early season and so greater Maruca population and hence more damage to cowpea. The higher population of PSBs in the late cropping season given in the results is consistent with the reports of earlier cowpea researchers such as Dina (1982).

Grain yield from mineral oils treated plots during the early season were $224.70 \mathrm{~kg} \mathrm{ha}^{-1}, 238.20 \mathrm{~kg} \mathrm{ha}^{-1}$, $397.00 \mathrm{~kg} \mathrm{ha}^{-1}$ and $498.20 \mathrm{~kg} \mathrm{ha}^{-1}$ for PMS, DPK, $A G O$ and CPM respectively. Apart from AGO, other treatments had yield values that were not significantly different. These low values probably were due to the delay and reduced flowering observed in the field. The study revealed that mineral oils can be reliable insecticides for cowpea growers if the delay and reduction of flowering can be removed (an area for further study). The CPM plots produced grains that were more than the grains from the mineral oils, showing that it is a more superior insecticide and confirmed grain yield increase when synthetic chemicals were applied to control insect pests (Jackai, 1993). The yield related components showed values that were nearly similar indicating that the chemical was not phytotoxic at $0.4 \%$ concentration and did not affect yield.

In the late season, apart from the CPM plots $\left(480.55 \mathrm{~kg} \mathrm{ha}^{-1}\right)$ yields in mineral oils were generally low. PMS, AGO and DPK yielded $63.44 \mathrm{~kg} \mathrm{ha}^{-1}$, $73.00 \mathrm{~kg} \mathrm{ha}^{-1}$ and $132.99 \mathrm{~kg} \mathrm{ha}^{-1}$ respectively. PMS had the least yield followed by AGO. The yield in the control was higher than the mineral oil treatments. The low yield in mineral oils may be attributed to delayed and scanty flowering as well as the sudden cessation of rains in the month of October. The scanty rains probably affected proper pod development leading to scanty yields. Most of the yield related parameters were low in values. This may also be due to weather factors, resulting in poor plant development and hence poor yields.

Grains yields were significantly higher in the early season $\left(325.44 \mathrm{~kg} \mathrm{ha}^{-1}\right)$ than late season $(181.77 \mathrm{~kg}$ $\mathrm{ha}^{-1}$ ) under the application of mineral oils at Asaba. The low yield in the late season may be due to the sudden weather change, marked largely by lack of rains $(217.4 \mathrm{~mm})$ and high temperatures $\left(28.0^{\circ} \mathrm{C}\right)$ in late October. These factors probably led to drying of leaves and water stress in the plant culminating in poor development. Moreover, the largely high pod damage, wrinkled seeds, low number of seeds per pod may have contributed to the very low yield at this season.

Cowpea production under mineral oils application have not been reported in Nigeria. Only synthetic chemicals for now are largely in use in the country. Mineral oils can be good components in insect pest management if their potentials are properly harnessed as is done in some parts of the world such as Israel (Emosairue personal communication).

\section{CONCLUSION}

The control of cowpea insect pests and moderate grain yield recorded in the study area indicate that mineral oils can be reliable non-conventional insecticides for cowpea growers, particularly if the delay and reduction in flowering are removed. Mineral oils could form new components in the overall management of cowpea pests in Nigeria.

\section{REFERENCES}

Afun, J.V.K., Jackai, L.E.N. and Hodgson, C.J. (1991) Calendar and monitored insecticide application for the control of cowpea pests. Crop Protection 10: 363-370.

Alabi, O.Y., Odebiyi, J.A. and Jackai, L.E.N. (2003) Field evaluation of cowpea cultivars (Vigna unguiculata (L) Walp.) for resistance to flower bud thrips (Megalurothrips sjostedti Trybom) Thysanoptera: Thripidae) International Journal of Pest Management. 49 (4), 287-291

ALdabel, F., Mensah, R. K. and Frerot, B. (2007). Effects of nC24 and nC27 petroleum spray oils on oviposition and egg survival of Ostrinia nubilalis Hubner (Lepidoptera, Pyralidae) and Trichogramma brassicae Bezdenko, Trichogrammatidae) adults on maize plants. International Journal of Pest Management (In press).

Arnason, J.T., Philogene, B.J.R. and Morand, P. (eds) (1989) Insecticides of plant origin . ACS Symposium Series No. 387, American chemical society. Washington, D.C. USA. 213 pp.

Dina, S. O. (1982) Interactions between rate, spray interval and number of applications of the synthetic pyrethroid Decis in Cowpea (Vigna unguiculata) pest control. J. Agric, Camb. 99. 471-478

IITA (1984) Annual Report for 1982. Ibadan, Nigeria

Jackai, L.E.N. (1983) Efficacy of Insecticide Application at different times of day against the legume pod borer 
Maruca vitrata (FAB) (Lepidoptera, Pyralidae, on cowpea in Nigeria. Prot. Ecol. 5:245-51

Jackai, L. E. N. (1993) The use of neem in controlling cowpea pests, IITA Research No 7. September, 1993

Jackai, L.E.N. (1985) Cowpea Entomology Research at IITA and its impact on food production in the tropics. Nigeria J. Ent. 6, 87-97

Jackai, L.E.N. and Daoust, R.A. (1986). Insect pests of cowpeas. Annual Review of Entomology 3195119

Jackai, L.E.N. and Singh, S.R. (1988) Screening Techniques for Host Plant Resistance to Insect Pests of cowpea. Tropical Grain Legume Bulletin 35: 2-18

Jackai, L.E,N., Roberts, J.M.F. and Singh, S.R. (1988) Cowpea seed treatment with carbosulfan potential for control of seedling pests. Crop Protection 7: 384-390.

Job, T.A., Maner, J.H. and Buitrago,J. (1983) Nigerian journal of Nutritional Sciences, 4 (1), 29-34

Karungi, J., Adipala, E., Ogenga-latigo, M.W., Kyamanywa, S. and Oyobo, N. (2000) Pest management in cowpea. Part 1. Influence of planting time and plant density on cowpea field pests infestation in eastern Uganda. Crop Prot. 19, 231-136.

Litsinger, J.A., Quirino, C.B., Lumaban, M.D. and Bandong, J.P. (1977), Grain Legume Pest Complex of Three Phillipine Rice-Based Cropping System. Cropping Program, IRRI. Los Banos. Philippines, 39.

Listsinger, J.A., Bendong, J.F., and Cruz, C.C. de la. (1983) Verifying and extending integrated pest control technology to small-scale farmers. Paper prepared for the international workshop on integrated pest control for tropical crop legumes, Goiania, Goias, Brazil, 4-9 April 1983.

Mensah, R. K., Frerot, B. and AL Dabel, F. (2005a). Effects of Petroleum Spray oils on oviposition behaviour and larval survival of Helicoverpa armigera (Lepidoptera: Noctuidae) and Ostrinia nubilalis (Lepidoptera:Pyralidae). International Journal of Pest Management 51 (2) 111 -119.
Mensah, R. K., Liang, W., Gibb, D., Coates, R. and Johnson, D. (2005b). Evaluation of nC27 Petroleum spray oil for activity of against Helicoverpa spp. on commercial cotton fields in Australia. International Journal of Pest Management 51 (1) 63-70.

Najar, R. A. J., Walter, G. H. and Mensah, R. K. (2006). Petroleum spray oil against cotton aphids in Australia: How effective are they? Proceedings 13th Australian Cotton Conference, 8-10 August 2006, Broadbeach, Gold Coast, Australia [CD-ROM].

Najar, R. A. J., Walter, G. H. and Mensah, R. K. (2007a). The efficacy of petroleum spray oils against Aphis gossypii Glover on cotton: (Part I) Mortality rates and sources of variation" Pest Management Science 63; 586-595.

Najar, R. A. J., Walter, G. H. and Mensah, R. K. (2007b). "The efficacy of a petroleum spray oil against Aphis gossypii Glover on cotton: (Part 2) Indirect effects of oil deposits". Pest Management Science 63; 596-607.

Ngakou, A., Parh, I. A. Ntonifor, N. N. Waga, D. N. and Nebane, C. L. N. (2006) Variations of Flower thrips (Megalurothrips sjostedti) and pod borer (Maruca vitrata) Pests and Cowpea flower abortion under caging and deltamethrin (R) spray conditions. Medwell Agricultural Journal 1(4): 328-334

Olatunde, J.A. Odebiyi, Chiang, H.S. and Jackai, L.E.N. (1991) Identification of sources of resistance in cowpea, Vigna unguiculata L. Walp. to Clavigralla tomentosicollis. Stal. (Hemipera: Coreidae) Insect Sci. Applic., 12 (4), 455-461

Rachie, K.O. (1985) Introduction. P. xxi xxviii. In: S.R. Singh and K.O. Rachie (eds). Cowpea research, production and utilization. Wiley New York.

Remison, S.U. (1978e) Cowpea agronomy works at National Cereals Research Institute. Paper presented at the 1st National meeting. On development of package. Recommendations for legume crops at N.C.R.I, Ibadan, 7-8 February.

Stern V. M. (1973). Economic threshholds. A. Rev. Entomol. 18. 259-280. 